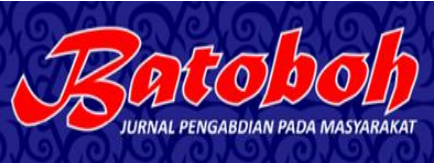

\title{
SOSIALISASI DAN DISEMINASI KEBIASAAN BARU (NEW NORMAL) KEPADA SISWA/I SDN 23 UJUNG GURUN MELALUI AUDIO VISUAL DAN MEDIA ONLINE
}

\author{
Novia Amirah Azmi \\ Gisky Andria Putra \\ Annisa Weriframayeni \\ Program Studi Ilmu Komunikasi/ Fakultas Ekonomi Bisnis \& Ilmu Sosial \\ Universitas Perintis Indonesia \\ Jl. Adinegoro KM. 17 Simp. Kalumpang Padang, Sumatera Barat Indonesia \\ noviaamirahazmi@gmail.com, gisky.andria@gmail.com, werif.nisa03@gmail.com
}

\begin{abstract}
ABSTRAK
Terhitung tanggal 4 Januari 2021, pemerintah Kota Padang resmi mengeluarkan izin pelaksanaan Proses Belajar Mengajar (PBM) secara tatap muka bagi Sekolah Dasar dan Sekolah Menengah Pertama. Kebijakan ini tentunya perlu diiringi dengan pelaksanaan protokol kesehatan di lingkungan sekolah. Jika lalai, maka diprediksi sekolah akan menjadi kluster penyebaran virus Covid-19. Sehingga perlu dilaksanakan kegiatan Pengabdian Kepada Masyarakat dalam bentuk sosialisasi dan diseminasi informasi penerapan kebiasaan baru (new normal) di SDN 23 Ujung Gurun, Kota Padang, Sumatera Barat. Lokasi ini menjadi menarik karena berada di Kawasan perkantoran dimana tentunya mobilitas masyarakat tinggi, dan potensi penyebaran Virus Covid-19 tinggi. Kegiatan ini diharapkan dapat mendorong penguatan pelaksanaan protokol kesehatan di lingkungan Sekolah Dasar. Pesertanya merupakan siswa-siswi kelas 4-6 dengan jumlah 20 orang.
\end{abstract}

Kata Kunci : Covid-19; diseminasi informasi; new normal; sosialisasi 
Jurnal Batoboh, Vol 6, No 1, Maret 2021

Novia Amirah Azmi, Gisky Andria Putra, Annisa Weriframayeni

\section{PENDAHULUAN}

Covid-19 masih menjadi wabah yang menakutkan bagi masyarakat, termasuk masyarakat Kota Padang. Hampir semua lini kehidupan masyarakat menjadi lumpuh karena virus ini. Beberapa kali kebijakan lockdown dilakukan oleh Pemerintah Kota Padang secara khusus dan Sumatera Barat secara umum untuk meminimalisasi penyebaran virus. Banyak sektor usaha terpaksa ditutup, kantor-kantor pemerintahan dan swasta bekerja dari rumah, sekolah dan universitas belajar secara daring.

Hampir satu tahun penuh, masyarakat terpaksa menyesuaikan diri dengan kondisi darurat yang terjadi. Terutama siswa-siswi dan mahasiswa. Mereka yang biasanya melaksanakan sekolah dengan tatap muka, mau tidak mau harus belajar dan membiasakan diri dengan metode pembelajaran dalam jaringan atau daring. Tidak hanya siswa dan mahasiswa yang merasa kesulitan, namun guru, dosen bahkan orang tua pun merasakan sulitnya perubahan kebiasaan cara belajar ini. Keluhan dari semua pihak pun diutarakan melalui Hall 76 media massa dan media sosial.

Melihat kondisi yang semakin kondusif dan terjadinya penurunan jumlah pasien positif covid-19, pemerintah Kota Padang resmi mengeluarkan kebijakan pelaksanaan Proses Belajar Mengajar (PBM) secara tatap muka terhitung tanggal 4 Januari 2021. Dalam aturan tersebut, tingkat pendidikan yang diizinkan ialah Sekolah Dasar (SD) dan Sekolah Menengah Pertama (SMP) setingkat. Pada awal pelaksanaan, untuk tingkat SD, siswa yang hadir ke sekolah di minggu pertama ialah siswa kelas 5 dan 6 dengan jumlah setengah dari total siswa setiap kelasnya. Pada minggu kedua, siswa kelas 1 sampai kelas 4 dengan jumlah setengah dari total siswa. Sedangkan di minggu ketiga, siswa kelas 1 hingga kelas 6 sudah mulai masuk bersamaan 
Jurnal Batoboh, Vol 6, No 1, Maret 2021

Novia Amirah Azmi, Gisky Andria Putra, Annisa Weriframayeni

dengan jumlah yang sama, setengah dari total siswa per masing-masing kelas. Tatap muka dilakukan selama 3 hari dalam satu minggu sedangkan 3 hari lainnya masih dilakukan secara daring (Melly Kartika Adelia, 2021).

Tingkat Sekolah Menengah Pertama (SMP) juga demikian, diminggu pertama hanya siswa kelas IX yang masuk dengan jumlah setengah dari total siswa. Kemudian di minggu kedua hanya siswa kelas VII dan VIII dengan jumlah yang sama. Sedangkan di minggu ketiga dan seterusnya siswa kelas VII, VIII dan IX dengan kapasitas 50\% dari total siswa per kelas. Sama dengan SD, siswa SMP sederajat juga hadir tatap muka tiga kali dalam sepekan dan tiga hari secara daring (Melly Kartika Adelia, 2021).

Kebijakan ini menurut Kepala Dinas Pendidikan Kota Padang, Habibul Fuadi, dikutip dari merdeka.com diambil untuk menjawab keresahan pihak orang tua dan sekolah yang menilai kegiatan belajar dalam jaringan (daring) tidak efektif karena tidak semua siswa memiliki perangkat elektronik untuk mengikuti pembelajaran (Raynaldo Ghiffari Lubabah, 2021). Kemudian Hall 77 metode ini juga dinilai membuat siswa kesulitan dalam memahami materi pembelajaran (Nila Chrisna Yulika, 2021). Kebijakan ini juga berdasarkan pertimbangan Kota Padang sudah termasuk daerah zona kuning, tidak lagi merah. Artinya jumlah warga yang terpapar virus Covid-19 sudah mulai berkurang dibandingkan dengan bulanbulan sebelumnya.

Bersamaan dengan aturan tersebut, pemerintah Kota Padang melalui Dinas Pendidikan Kota Padang juga telah mengimbau pihak sekolah untuk menyiapkan semua sarana prasarana pelaksanaan protokol kesehatan, mulai dari tempat cuci tangan, pengecekan suhu bagi setiap murid dan guru yang memasuki lingkungan sekolah dan mewajibkan penggunaan masker. Sebelumnya semua 
Jurnal Batoboh, Vol 6, No 1, Maret 2021

Novia Amirah Azmi, Gisky Andria Putra, Annisa Weriframayeni

ruangan kelas juga telah dilakukan penyemprotan (Rahmadhani, 2020). Semua hal ini dilakukan untuk meminimalisir kemungkinan sekolah menjadi kluster baru penyebaran Covid19.

\section{Permasalahan Mitra}

Berdasarkan analisis situasi dan diskusi awal dengan pihak SDN 23 Ujung Gurun, maka dapat dirumuskan beberapa masalah sebagai berikut :

1. Belum cukupnya pengetahuan, sikap, dan kemampuan siswa/i dalam menerapkan kebiasaan baru (new normal) di lingkungan SDN 23 Ujung Gurun.

2. Belum adanya upaya diseminasi informasi bagi siswa di lingkungan SDN 23 Ujung Gurun dengan menggunakan media audio visual yang menarik.

3. Belum adanya aktivitas diseminasi informasi protokol kesehatan pada platform media sosial siswa/i.

Copyright (C) 2021, Jurnal Batoboh, ISSN 2548-5458 (print), ISSN 2599-1906 (online)

\section{Solusi Permasalahan}

Untuk mengatasi permasalahan mitra yang telah dijabarkan di atas, maka perlu dirancang sebuah kegiatan yang dirasa cukup mampu untuk mendorong penguatan penerapan kebiasaan baru (new normal) di lingkungan SDN 23 Ujung Gurun, Kota Padang. Beberapa kegiatan yang perlu dirancang adalah sebagai berikut :

1. Sosialisasi penguatan penerapan kebiasaan baru (new normal) di lingkungan SDN 23 Ujung Gurun, Kota Padang.

2. Kegiatan Diseminasi informasi bagi siswa di lingkungan SDN 23 Ujung Gurun, Kota Padang dengan menggunakan media audio visual yang menarik.

3. Penyebarluaskan Video Animasi tentang aturan protocol Kesehatan dengan memanfaatkan media sosial siswa/i SDN 23 Ujung Gurun, Kota Padang. 
Jurnal Batoboh, Vol 6, No 1, Maret 2021

Novia Amirah Azmi, Gisky Andria Putra, Annisa Weriframayeni

Dengan adanya kegiatan ini diwajibkan untuk mengenakan masker diharapkan seluruh siswa/i dapat saat berada di lokasi (lapangan).

menerapkan kebiasaan baru (new normal)

2. Mengatur tata letak kursi maupun di lingkungan SDN 23 Ujung Gurun, meja di kelas dengan jarak minimal 1 Hall 79 Kota Padang melalui penyajian video (satu) meter. animasi yang menarik dan juga 3. Mencuci tangan sebelum memasuki menyebarluaskannya pada media sosial mereka.

\section{PEMBAHASAN}

\section{A. Tahap Persiapan}

Kegiatan pengabdian kepada masyarakat ini membutuhkan beberapa tahapan persiapan agar kegiatan dapat berjalan dengan semestinya. Di tengah pandemi Covid-19 yang kita rasakan saat ini tentunya kegiatan pengabdian kepada masyarakat di lapangan harus memperhatikan dan menerapkan protokol Kesehatan sebagai wujud upaya memutus mata rantai penyebaran virus Covid-19 ini, seperti :

1. Dalam pelaksanaan kegiatan, pengabdi, siswa/i SDN 23 Ujung Gurun, Kota Padang beserta stakeholder

\section{B. Tahap Pelaksanaan}

1. Sosialisasi penguatan penerapan kebiasaan baru (new normal) di lingkungan SDN 23 Ujung Gurun, Kota Padang.

Pada tahap pelaksanaan, kegiatan sosialisasi dilakukan dengan memberikan materi kepada siswa/i SDN 23 Ujung Gurun, Kota Padang selama \pm 60 (enam puluh) menit. Tahap sosialisasi ini harus dilakukan dengan baik agar hasil yang diharapkan dapat terwujud dan efektif. Wujud pembekalan materi dilakukan melalui metode ceramah dengan memanfaatkan peralatan visual 
Jurnal Batoboh, Vol 6, No 1, Maret 2021

Novia Amirah Azmi, Gisky Andria Putra, Annisa Weriframayeni

seperti screen projector dan juga dukungan audio yang memadai.

Beberapa poin materi yang disampaikan adalah sebagai berikut:

a. Apa itu Covid-19?

Virus yang menyerang system pernafasan manusia dengan gejala umum seperti (demam dan setidaknya satu tanda/gejala penyakit pernapasan, seperti batuk, sesak napas) (Diah Handayani, Dwi Rendra Hadi, Fathiyah Isbaniah, Erlina Burhan, 2020).

b. Darimana asal Covid-19?

Virus corona merupakan zoonosis, sehingga terdapat kemungkinkan virus berasal dari hewan dan ditularkan ke manusia (Diah Handayani, Dwi Rendra Hadi, Fathiyah Isbaniah, Erlina Burhan, 2020).

c. Bagaimana penularannya Covid-19?

Penularan antar manusia (human to human), yaitu diprediksi melalui droplet dan kontak dengan virus yang dikeluarkan dalam droplet (Diah
Handayani, Dwi Rendra Hadi, Fathiyah Isbaniah, Erlina Burhan, 2020). Droplet merupakan paparan tetesan dari pernapasan yang membawa virus (farmasetika.com, 2020).

d. Bagaimana Langkah mengurangi resiko penyebaran Covid-19?

Memakai Masker, Mencuci Tangan, dan Menjaga Jarak (Titis Nurdiana, 2020).

Pemaparan materi dikemas dengan Bahasa yang ringan dan design menarik agar siswa/i mampu menyerap informasi tersebut dengan sempurna. Pada tahap akhir juga dibuka sesi tanya jawab terkait materi yang telah di paparkan sebelumnya kepada siswa/i SDN 23 Ujung Gurun, kota Padang. Siswa/i dinilai cukup antusias dengan materi yang telah disampaikan, hal ini terlihat dengan aktifnya siswa/i dalam memberikan pertanyaan.

Pada prinsipnya, penanaman perilaku kebiasaan baru (new normal) Copyright (C) 2021, Jurnal Batoboh, ISSN 2548-5458 (print), ISSN 2599-1906 (online)
Hal| 80 


\section{Jurnal Batoboh, Vol 6, No 1, Maret 2021}

Novia Amirah Azmi, Gisky Andria Putra, Annisa Weriframayeni

untuk anak sekolah dasar sangat penting dan bermanfaat untuk masa depan. Pemahaman adaptasi kebiasaan baru (new normal) sebagai upaya pemutusan mata rantai pandemi Covid-19 akan lebih baik dilakukan sejak dini, yaitu masih dalam sekolah dasar. Karena anak sekolah dasar akan membawa pengalaman belajarnya saat ia menjadi dewasa.

2. Diseminasi informasi bagi siswa di lingkungan SDN 23 Ujung Gurun, Kota Padang dengan menggunakan media audio visual yang menarik.

Pada tahap berikutnya, kegiatan yang dilakukan adalah penayangan video (audio visual) animasi terkait protokol kesehatan pandemi Covid-19 kepada siswa/i SDN 23 Ujung Gurun, Kota Padang. Video tersebut dikemas dengan konsep yang menarik perhartian (eyecatching) serta dukungan audio yang eufoni. Eufoni merupakan istilah yang mengartikan kombinasi bunyi yang dianggap enak didengar (Eufoni, 2017).
Visualisasi pada video di kemas dengan penuh warna (fullcolor), sedangkan untuk audio, digunakan tema audio funny, sehingga dengan hal ini, memungkinkan Hal| 81 untuk menarik perhatian siswa/i SDN 23 Ujung Gurun, kota Padang.

Pada video tersebut terdapat pesanpesan tentang $3 \mathrm{M}$, di antaranya :

a. Memakai Masker

b. Mencuci Tangan

c. Menjaga Jarak

Visualisasi dari video tersebut adalah sebagai berikut :

1. Scene 1

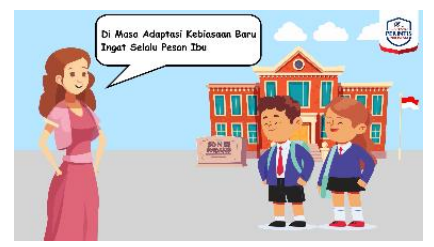

Pada scene 1 ini, visual yang dimunculkan adalah sosok seorang ibu sedang berdiri di hadapan 2 orang siswa/i sekolah dasar dengan background Gedung Sekolah, sebuah Tugu bertuliskan SDN 23 Padang, serta bendera merah putih berkibar pada tiang 
Jurnal Batoboh, Vol 6, No 1, Maret 2021

Novia Amirah Azmi, Gisky Andria Putra, Annisa Weriframayeni

di samping Gedung Sekolah. Teks yang

dimunculkan adalah perkataan seorang ibu "Di masa adaptasi kebiasaan baru, ingat selalu pesan ibu".

2. Scene 2

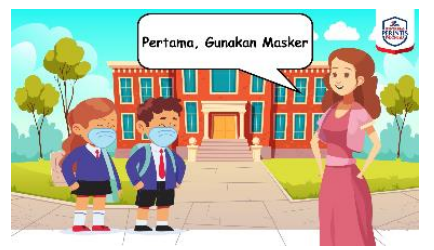

Pada scene 2, visual yang munculkan adalah sosok seorang ibu sedang berdiri di hadapan 2 orang siswa/i sekolah dasar dengan background Gedung Sekolah, dan halaman sekolah. Teks yang dimunculkan adalah perkataan seorang ibu "Pertama, Gunakan Masker".

3. Scene 3

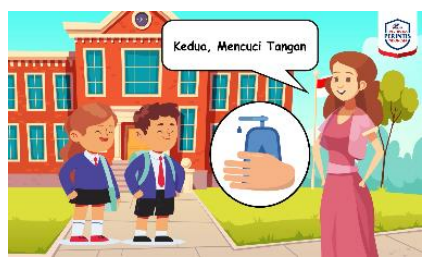

Pada scene 3, visual yang munculkan adalah sosok seorang ibu sedang berdiri di hadapan 2 orang siswa/i sekolah dasar dengan Hal| 82 background Gedung Sekolah, halaman sekolah, bendera merah putih yang berkibar di tiang bendera, serta gambar handwash. Teks yang dimunculkan adalah perkataan seorang ibu "Kedua, Mencuci Tangan".

4. Scene 4

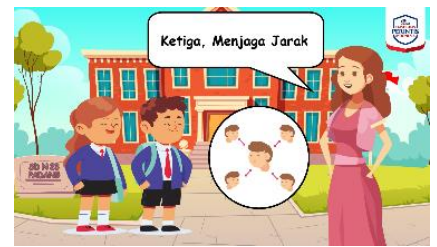

Pada scene 4, visual yang munculkan adalah sosok seorang ibu sedang berdiri di hadapan 2 orang siswa/i sekolah dasar dengan background Gedung Sekolah, halaman sekolah, bendera merah putih yang berkibar di tiang bendera, Tugu SDN 23 Padang, serta gambar physical distancing. Teks yang dimunculkan adalah 
Jurnal Batoboh, Vol 6, No 1, Maret 2021

Novia Amirah Azmi, Gisky Andria Putra, Annisa Weriframayeni

perkataan seorang ibu "Ketiga, Menjaga Jarak".

5. Scene 5

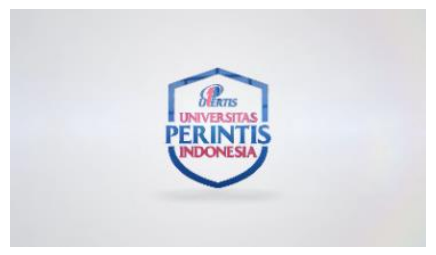

Pada scene 5, visual yang munculkan adalah Logo Universitas Perintis Indonesia dengan Latar Belakang Putih, sebagai institusi yang melakukan pengabdian kepada masyarakat.

\section{Penyebarluaskan Video Animasi} tentang aturan protocol Kesehatan dengan memanfaatkan media sosial siswa/i SDN 23 Ujung Gurun, Kota

\section{Padang.}

Tahapan ini merupakan tahapan terakhir dari kegiatan pengabdian kepada masyarakat yang dilakukan oleh Program Studi Ilmu Komunikasi Universitas Perintis Indonesia. Siswa/i diminta untuk menyebarluaskan video (audio visual) animasi tersebut pada akun media sosial mereka masingmasing. Hal ini ditujukan agar penerima Hal| 83 manfaat dari kegiatan ini tidak hanya pada siswa/i SDN 23 Ujung Gurun, Kota Padang. Namun, juga dapat dirasakan manfaatnya oleh orang banyak melalui platform media social.

\section{Evaluasi Pelaksanaan Kegiatan}

Evaluasi kegiatan Pengabdian Kepada Masyarakat ini dilakukan dengan memantau secara langsung pelatihan yang diselenggarakan, apakah peserta dapat mengikuti pelatihan dengan baik atau penyampaian materi terlalu cepat atau tidak (Sunarsan Sitohang, 2020). Dari hasil pengamatan, peserta Pengabdian Kepada Masyarakat (Siswa/i SDN 23 Ujung Gurun) dinilai cukup antusias dan tertarik dengan materi yang disampaikan. Sehingga metode ceramah dengan memanfaatkan design audio visual yang menarik, serta menyebarluaskan konten tersebut pada 
Jurnal Batoboh, Vol 6, No 1, Maret 2021

Novia Amirah Azmi, Gisky Andria Putra, Annisa Weriframayeni

media social masing-masing peserta dapat dimanfaatkan untuk kegiatan yang relevan kedepannya.

\section{SIMPULAN}

Kegiatan Sosialisasi dan Diseminasi Informasi Penerapan Kebiasaan Baru (new normal) Kepada Siswa/i SDN 23 Ujung Gurun Melalui Perancangan Audio Visual dan Pemanfaatan Media Online bertujuan untuk meningkatkan kesadaran siswa/i dalam menerapkan kebiasaan baru (new normal). Pesan yang disampaikan adalah 3M, yaitu ; 1) Memakai Masker, 2) Mencuci Tangan, dan 3) Menjaga Jarak. Melalui perancangan Video (audio visual) Animasi yang eyecatching (menarik) dan dukungan audio yang eufoni (bunyi yang dianggap enak didengar), siswa/i cukup tertarik dan antusias dalam mengikuti kegiatan sampai selesai. Disamping itu, semua siswa/i SDN 23 Ujung Gurun, Kota Padang juga melakukan upaya deseminasi informasi tersebut pada akun media sosial mereka, sehingga diharapkan juga banyak pihak diluar sana yang mempu menerapkan protokol Kesehatan.

\section{KEPUSTAKAAN}

Diah Handayani, Dwi Rendra Hadi, Fathiyah Isbaniah, Erlina Burhan, H. A. (2020). Penyakit Virus Corona 2019. Jurnal Respirologi Indonesia, 40(2), 119-129.

Eufoni. (2017). Eufoni. Wiktionary. https://id.wiktionary.org/w/index.ph p?title=eufoni\&oldid $=854584$

farmasetika.com. (2020). CDC Ungkap

Cara Pencegahan Penularan COVID-19 Lewat Udara "Airborne." https://farmasetika.com/2020/10/07/c dc-ungkap-cara-pencegahanpenularan-covid-19-lewat-udaraairborne/

HENDRA, H. (2020). Pelatihan Desain Gerabah Dengan Teknik Batik DI SMKN1 Kecamatan Luak Kabupaten 50 Kota. Batoboh, 5(2).

https://doi.org/10.26887/bt.v5i2.1296 


\section{Jurnal Batoboh, Vol 6, No 1, Maret 2021}

Novia Amirah Azmi, Gisky Andria Putra, Annisa Weriframayeni

Melly Kartika Adelia. (2021). Kota Padang

Mulai Sekolah Tatap Muka Jenjang SD dan SMP pada 4 Januari.

https://akurat.co/news/id-1256256-

read-kota-padang-mulai-sekolah-

tatap-muka-jenjang-sd-dan-smp-

pada-4-januari

Nila Chrisna Yulika. (2021). Padang Akan

Memulai Sekolah Tatap Muka pada 4

Januari 2021.

https://www.liputan6.com/news/rea

d/4447569/padang-akan-memulai-

sekolah-tatap-muka-pada-4-januari2021

Rahmadhani. (2020). “Kota Padang Bersiap Sekolah Tatap Muka, 3.000 Guru Jalani

Tes Swab, 4 Positif Covid-19."

https://regional.kompas.com/read/20

20/12/15/20281901/kota-padang-

bersiap-sekolah-tatap-muka-3000-

guru-jalani-tes-swab-4-

positif?page=all https://www.merdeka.com/peristiwa /padang-mulai-sekolah-tatap-muka4-januari-

2021.html\#: :text=Merdeka.com -

Hal| 85

Pemerintah Kota Padang,dasar dan sekolah menengah pertama.

Sunarsan Sitohang, C. E. (2020).

PEMBINAAN ADMINISTRASI

DENGAN MEMANFAATKAN

SOFTWARE APPLICATION

Sunarsan. 5458.

https://doi.org/http://dx.doi.org/10.2

6887/bt.v5i2.1300

Titis Nurdiana. (2020). Serentak disiplin

jalankan 3M: Kunci menekan

penyebaran dan penularan virus corona.

https://kesehatan.kontan.co.id/news/

serentak-disiplin-jalankan-3m-kunci-

menekan-penyebaran-dan-

penularan-virus-corona

Raynaldo Ghiffari Lubabah. (2021).

Padang Mulai Sekolah Tatap Muka 4

Januari 2021.

Copyright (C) 2021, Jurnal Batoboh, ISSN 2548-5458 (print), ISSN 2599-1906 (online) 